Joanna Lubecka

Akademia Ignatianum w Krakowie, IPN Kraków

\title{
Między obawą a nadzieją - poszukiwanie nowej roli zjednoczonych Niemiec na arenie międzynarodowej. Zarys debaty wybranych polityków i intelektualistów w pierwszej połowie lat go.
}

Wydarzenia lat 1989-1990, w konsekwencji których doszło do obalenia systemu komunistycznego w Europie Środkowej i Wschodniej, rozpadu bloku sowieckiego i samego ZSRS oraz do zjednoczenia Niemiec, stworzyły zupełnie nową sytuację i wymagały formułowania nowych zasad, celów, priorytetów w polityce zagranicznej poszczególnych państw. O ile w przypadku wielu krajów był to proces trudny, o tyle przypadek Niemiec był pod każdym względem szczególny. Żadne inne państwo nie było tak bardzo obciążone swoją historią. Zjednoczenie Niemiec jednoznacznie nasuwało skojarzenia i pytania o ich rolę na arenie międzynarodowej. W rezultacie zjednoczenia powstało największe i najludniejsze państwo Europy, najsilniejsze gospodarczo, a równocześnie mające najczarniejsze karty w historii Europy Zachodniej. Politycy, intelektualiści, zarówno niemieccy, jak i z innych krajów zachodniej i środkowej Europy, z obawą zadawali sobie pytania o trwałość niemieckiej demokracji, o drogę, którą wybiorą Niemcy, o rolę, jaką będą chcieli w przyszłości odgrywać. Inni z nadzieją patrzyli na gospodarczego kolosa i liczyli, że w niepewnym świecie, pełnym nowych zagrożeń i konfliktów, w których Europa brała udział, przyda się wsparcie 
niemieckich pieniędzy, a być może również sił zbrojnych ${ }^{1}$. Oczekiwano większego zaangażowania zjednoczonych Niemiec w politykę światową i "przejęcia większej odpowiedzialności".

W perspektywie kilku lat od zjednoczenia Niemiec nie powstała jednak nowa koncepcja polityki zagranicznej RFN. Poszczególne posunięcia polityczne wynikały raczej z doraźnej reakcji na konkretne wydarzenia, nie zaś z realizacji założeń i celów zwartej i klarownej koncepcji polityki zagranicznej. Przyczyn takiej sytuacji było wiele. Przede wszystkim nie udało się kreatorom polityki niemieckiej stworzyć takiej koncepcji. Brak silnej osobowości w ministerstwie spraw zagranicznych po odejściu Hansa Dietricha Genschera również nie sprzyjał tworzeniu nowej idei polityki zagranicznej, uwzględniającej ówczesną pozycję i rolę zjednoczonych Niemiec. Klaus Kinkel, w przeciwieństwie do swego poprzednika, był uważany za postać bezbarwną, bez charakteru, i nie potrafił stworzyć nowej, odpowiadającej ówczesnym wyzwaniom koncepcji polityki zagranicznej.

Niniejszy artykuł jest próbą ukazania różnych idei i koncepcji tworzących się i dyskutowanych w RFN w trakcie i bezpośrednio po zjednoczeniu Niemiec, dlatego też tekst bazuje przede wszystkim na dokumentach, wypowiedziach, artykułach z pierwszych pięciu lat tym wydarzeniu, niejako in statu nascendi koncepcji, pomysłów na miejsce zjednoczonych Niemiec na arenie międzynarodowej. Przedmiotem analizy są przede wszystkim wypowiedzi polityków i politologów, a więc przedstawicieli „oficjalnej historiografii". Włączenie do analizy przedstawicieli literatury, autorytetów kultury, choć ze wszech miar wskazane ze względów merytorycznych, przekracza jednak rozmiary artykułu naukowego. Już pobieżny przegląd opinii wykazuje, że głosy polityków wyraźnie odstają swoją powściągliwością od poglądów politologów, w których czasem pojawiają się nieco odważniejsze pomysły. W zakończeniu artykułu zostanie przedstawiona ówczesna krytyka niektórych międzynarodowych posunięć rządu federalnego,

1. Zasadniczy problem dotyczył konieczności zmiany prawa niemieckiego, zabraniającego jednostkom Bundeswehry udziału w akcjach poza terytorium państw członkowskich NATO. Dopiero 12 VII 1994 Federalny Trybunał Konstytucyjny uznał, iż udział Bundeswehry w ramach systemu kolektywnego bezpieczeństwa, poza terytorium NATO nie jest sprzeczny z konstytucją. Urteil des Bundesverfassungsgericht zum Einsatz der Bundeswehr im Rahmen von System kollektiver Sicherheit vom 12. Juli 1994, Dokumente und Zeitgeschehen, „Blätter für deutsche und internationale Politik" 1994 Nr. 4. 
co pokazuje też, że w niektórych przypadkach działania Niemiec różniły się od ostrożnej retoryki.

Warto też zaznaczyć, iż wiele z przedstawionych w latach 90. postulatów zostało uwzględnionych w późniejszych koncepcjach polityki zagranicznej Niemiec (szczególnie za rządów Angeli Merkel).

\section{Nowa sytuacja RFN}

Można zaryzykować tezę, że zmiany w Europie w latach 1989-1990 były zaskoczeniem dla większości polityków i społeczeństw. Mimo prowadzonych na zachodzie Europy badań socjologicznych i politologicznych nikt nie przewidział, przynajmniej w przybliżonym czasie, destrukcji systemu komunistycznego, rozpadu ZSRS i zjednoczenia Niemiec. Wydarzenia te, pomimo wielu negatywnych następstw, z perspektywy czasu są oceniane pozytywnie. Odejście od systemu komunistycznego w Europie Środkowej i Wschodniej zostało przeprowadzone bez przelewu krwi, natomiast Niemcy zrealizowały swój najważniejszy cel polityczny - zjednoczenie dwóch państw niemieckich.

Mimo że zjednoczone Niemcy nazywa się "największym zwycięzcą okresu zimnej wojny", to jednak poprawa sytuacji w aspekcie polityki zagranicznej i bezpieczeństwa była w znacznym stopniu pozorna². Owszem, zmieniły się niektóre wyznaczniki, pozytywnym aspektem z pewnością był fakt, że Niemcy przestały być państwem frontowym między dwoma systemami polityczno-militarnymi, a powstanie w Europie Środkowej demokratycznych państw, szukających przyjaznych kontaktów oraz postrzegających zjednoczone Niemcy jako ważnego partnera politycznego i gospodarczego, również stabilizowało sytuację w regionie.

Wielu autorów podkreśla jednak, iż wcześniejsze położenie RFN było z politycznego punktu widzenia dużo prostsze. Charakteryzowało się klarownością sytuacji, wynikającą przede wszystkim z bipolarności świata, która najbardziej bezpośrednio dzieliła Europę. Konflikt Wschód-Zachód jasno określał orientację i kierunki polityki zagranicznej RFN. Multilateralny świat okazał się dużo bardziej skomplikowany i stawiał przed polityką zagraniczną znacznie większe wyzwania. Politycy i politolodzy niemieccy widzieli w nowej sytuacji bardzo wiele utrudnień dla niemieckiej polityki zagranicznej.

2. W. R. Smyser, Das Ausland und die Außenpolitik des neuen Deutschland , Internationale Politik“ 1995 Nr. 4, s. 45. 
Peter Weilemann określił zmianę sytuacji Niemiec jako "przejście od stabilnego zagrożenia do zagrożenia przez niestabilność"3. Podstawową przyczynę tej niestabilności widział w powstałej po upadku ZSRR próżni bezpieczeństwa w Europie Wschodniej. Wcześniejsze zagrożenia dla RFN były proste do identyfikacji, czego nie można było powiedzieć o nowych. Znaczne utrudnienia stwarzała spuścizna historyczna okresu powojennego, dotyczyło to zwłaszcza sfery mentalnej. Kategorie i schematy myślenia, rozumienia sytuacji politycznej, opinie i sądy ukształtowane często przez propagandę zimnowojenną zmieniały się bardzo powoli. 45 lat myślenia kategoriami konfliktu Wschód-Zachód pozostawiło trwałe ślady w mentalności Europejczyków, w tym szczególnie Niemców.

Wybitny niemiecki politolog Karl Kaiser napisał, iż zakończenie konfliktu Wschód-Zachód "obdarowało" (bescheren) Niemców problemami i wyzwaniami, do których nie byli przygotowani ${ }^{4}$. Z kolei amerykański politolog William R. Smyser podkreślał, że sytuacja międzynarodowa Niemiec po zjednoczeniu stała się paradoksalnie trudniejsza przede wszystkim z powodu sprzecznych oczekiwań i żądań. W bipolarnym świecie Niemcy miały sprzymierzeńców i przeciwników, teraz mają sprzymierzeńców i „przyjaciół, którzy nie zawsze okazują się sprzymierzeńcami"5. Być może brak określenia konkretnych celów i priorytetów niemieckiej polityki zagranicznej wynikał z niechęci zrażania niektórych partnerów przy równoczesnej niemożności sprostania ich wymaganiom. Oczywiste było jednak, że Niemcy będą musieli dokonać wyboru konkretnej drogi, nawet gdyby miała ona wiele krajów zniechęcić czy rozczarować, co Smyser uważa za nieuniknione. Ostrzegał, że bez dokonania takiego wyboru Niemcy zostaną oskarżone o prowadzenie „polityki huśtawki" (Schaukelpolitik) i staną się niepewnym partnerem, co w przypadku Niemiec może mieć szczególnie daleko idące konsekwencje ${ }^{6}$.

Nowa sytuacja Niemiec wynikała również z odzyskania pełnej suwerenności, którą ograniczał najpierw statut okupacyjny z 8 kwietnia 1949 r.,

3. P. Weilemann, Deutsche Außenpolitik: Herausforderungen und Verantwortung, wykład wygłoszony w Uniwersytecie Jagiellońskim, X 1994, tekst w posiadaniu autora.

4. K. Kaiser, Deutsche Außenpolitik in der Ära des Globalismus. Zwischen Interdependenz und Anarchie, "Internationale Politik" 1995 Nr. 1, s. 27.

5. W. R. Smyser, Das Ausland..., dz. cyt., s. 45; W. R. Smyser, The Economy of United Germany: Colossus at the Crossroads, New York 1993.

6. W. R. Smyser, Das Ausland und die Außenpolitik..., dz. cyt., s. 45 
a potem nieco mniej restrykcyjne postanowienia Układu Paryskiego z 1955 r. Jednak z formalno-prawnej perspektywy pełną suwerenność RFN odzyskała wraz z podpisaniem Układu o ostatecznej regulacji w odniesieniu do Niemiec z 12 września 1990 r. ${ }^{7}$ Ta nowa sytuacja oznaczała nie tylko konieczność faktycznego przejęcia odpowiedzialności, ale również miała szerszy aspekt, dotyczący sfery mentalnej. Czy kraje Europy i świata były wówczas gotowe na podjęcie przez Niemcy nowej, aktywniejszej roli, na globalizację niemieckiej polityki zagranicznej? Czy sami Niemcy byli gotowi na większe zaangażowanie polityczne w świecie?

Kaiser podkreśla zależność między aktywną polityką niemiecką a odpowiedzialnością Niemców w trzech płaszczyznach: przed własnym społeczeństwem, w ramach Unii Europejskiej oraz w skali globalnej. Jak zauważał, nie było to łatwe zadanie dla państwa, które przez 45 lat było "karłem politycznym". Mimo tych trudności autor wypowiada się jednak za aktywną rolą Niemiec: „jest przeznaczeniem wielkich mocarstw, do których Niemcy obecnie znowu należą, być nie tylko użytkownikiem, lecz w odróżnieniu od małych państw, również kształtować politykę międzynarodową i być w niej aktywnym"8.

Bardzo interesująco przedstawił nowe położenie zjednoczonych Niemiec Smyser. Nazywa je „państwem środka", którego cechą charakterystyczną jest czynnik łączenia. Według autora Niemcy pełnią lub mogą pełnić funkcję elementu łączącego na wielu płaszczyznach, jako kraj łączący wschód Europy z zachodem, wysunięty najbardziej na wschód kraj UE, mający silne powiązania gospodarcze i polityczne z Europą Środkową i Wschodnią, a równocześnie kraj najbardziej aktywny w polityce integracji europejskiej, kraj łączący bogate narody Zachodu i rozwijające się kraje Europy Środkowej i Wschodniej. W aspekcie gospodarczym są Niemcy elementem łączącym socjalną gospodarkę rynkową Europy i liberalny rynek amerykański. Szansą dla Niemiec jest podjęcie aktywności politycznej z wykorzystaniem tych właśnie powiązań politycznych i gospodarczych. Oznacza to trudny w realizacji multilateralizm w polityce zagranicznej, jednak równocześnie mógłby on zapewnić zjednoczonym Niemcom silną,

7. Zgodnie z brzmieniem art. 7 tego układu RFN po zjednoczeniu uzyskała pełną suwerenność oraz prawo wyboru sojuszy politycznych i militarnych (art. 6). Szerzej o kwestii suwerenności RFN: D. Janicka, Ustawa zasadnicza w praktyce Republiki Federalnej Niemiec (1949-1989), Toruń 2009.

8. K. Kaiser, Deutsche Außenpolitik..., dz. cyt., s. 34 . 
odpowiadającą ich pozycji gospodarczej pozycję na arenie polityki międzynarodowej. Pod tym względem rok 1989 znacznie zmienił perspektywę patrzenia na Niemcy. Odbudowa państwa niemieckiego i jego sukcesy gospodarcze często wzbudzały zazdrość, ale status RFN jako "politycznego karła" nie budził zastrzeżeń natury politycznej. Samo zjednoczenie Niemiec wywołało jednak dość sceptyczne reakcje9 ${ }^{9}$ Po 1989 r. każde kontrowersyjne posunięcie rządu federalnego powodowało oskarżenia m.in. o agresywne forsowanie interesów narodowych ${ }^{10}$.

Nowa sytuacja międzynarodowa była kreowana również przez przewartościowanie dotychczasowych zagrożeń, charakterystycznych dla okresu zimnej wojny. Kompleksowo ujmuje je i analizuje Karl Kaiser w wielu swoich publikacjach ${ }^{11}$. Wszystkie nowe zagrożenia określa jednym hasłem „wzrost anarchii". Za główne przyczyny tego zjawiska autor uznaje m.in. gwałtowny wzrost poczucia prawa do samostanowienia (czy każda z około 3,5 tys. grup etnicznych istniejących na świecie ma prawo stworzyć swoje własne państwo?), upadek autorytetu politycznego państwa (np. były ZSRS, Afryka), zwiększenie zakresu przyczyn konfliktów (np. brak postępu technicznego, wspieranie terrorystów przez niektóre państwa, szczególnie islamskie, poszerzanie się obszarów ubogich w wodę), migracje na wielką skalę, terroryzm (Kaiser przewidywał powrót terroryzmu w krajach demokratycznych, w tym również w RFN). Rola, jaką mogłyby odegrać Niemcy, miałaby polegać przede wszystkim na zapobieganiu konfliktom przez środki dyplomatyczne, wypracowaniu koncepcji działań antykryzysowych, działaniu prewencyjnym poprzez wspieraniu rozwoju ekonomicznego, popieraniu ustroju demokratycznego.

9. Amerykański historyk Harold James napisał w swojej książce Deutsche Identität 1770-199o (Frankfurt-New York 1991): „Jak w roku 1806, czy 1870, jak w 1914 czy 1939, tak i w roku 1990 problem niemiecki zagraża międzynarodowemu porządkowi".

10. M. i S. Greiffenhagen, Hypothek der Vergangenheit. Belastungen der Außenpolitischen Handlungsfähigkeiten, "Internationale Politik" 1996 Nr. 8.

11. M.in. Deutsche Außenpolitik..., dz. cyt.; Außenpolitik in einer neuen Welt: der Wandel der internationalen Rahmenbedingungen, w: Die Zukunft der deutschen Ausenpolitik. Symposium des Forschungsinstituts der Deutschen Gesellschaft fur Ausenpolitik am 19. Oktober 1992, Hrsg. K. Kaiser, H. W. Maull, Bonn 1993; Das vereinigte Deutschland in der internationalen Politik, w: Deutschlands neue Außenpolitik, Bd. 1, Grundlage, München 1994. 


\section{Zarys nowych celów i priorytetów w wypowiedziach}

najważniejszych polityków niemieckich.

Analizując ówczesne mowy, artykuły, wywiady polityków, trzeba jednoznacznie stwierdzić, iż nie wypowiadali oni żadnych kategorycznych sądów. Powtarzały się sformułowania dotyczące konieczności podjęcia większej odpowiedzialności międzynarodowej, ale równocześnie podkreślano tradycję niemieckiej powojennej "kultury powściągliwości" (Kultur der Zurückhaltung $)^{12}$. Próby odnalezienia własnej, nowej linii polityki zagranicznej Niemiec na początku lat 90. musiały uwzględniać zarówno wyzwania, jakie stawia nowa sytuacja w Europie i na świecie, w miarę możliwości oczekiwania innych państw kierowane względem nich, jak i również sporą dozę nieufności wobec nowo powstałego potężnego państwa.

Trudno jednoznacznie określić cele, a zwłaszcza priorytety polityki zagranicznej Niemiec w latach 9o. Można jednak wyodrębnić kilka z nich, co do których w Niemczech panowała zgoda. Szczególnie kanclerz Helmut Kohl wielokrotnie postulował konieczność wzięcia przez Niemcy większej odpowiedzialności, np. przez udział w akcjach pokojowych ONZ, budowanie stabilnego otoczenia wokół Niemiec, zarówno na wschodzie jak i na zachodzie ${ }^{13}$. Kohl podkreślał, że zjednoczone Niemcy nie mogą stracić zaufania międzynarodowego, dlatego też tak ważna jest ścisła współpraca z Sojuszem Północnoatlantyckim oraz Unią Europejską. Kohl jasno i dobitnie formułował postulat integracji tzw. reformatorskich, łączącej kraje Europy Środkowo-Wschodniej z Unią Europejską, czego ówcześnie nie popierała większość krajów członkowskich. Wypowiedzi kanclerza Kohla nie poruszały kontrowersyjnych problemów polityki zagranicznej. Były one bardzo ostrożne i nie nawiązywały do dyskusji toczącej się w niemieckich kołach naukowych i szerokich kręgach intelektualnych. Kohl podkreślał raczej aspekty ewolucji i kontynuacji.

12. Kultura powściągliwości to częste określenie używane przez samych Niemców, a dotyczące przede wszystkim sfery polityki zagranicznej i bezpieczeństwa. Oznacza sceptyczne nastawienie do indywidualistycznych działań RFN na arenie międzynarodowej oraz stosowania siły militarnej. Niemiecka opinia publiczna jest wyjątkowo uwrażliwiona na ten problem, choć podejmuje się od lat liczne dyskusje na ten temat.

13. "Bulletin", 22 III 1991, „Bulletin", 10 II 1993; M. Tomala, Dyskusja na temat polityki zagranicznej zjednoczonych Niemiec, w: Polityka zagraniczna zjednoczonych Niemiec, red. T. Pawlak-Lis, Warszawa 1994 (Studia i Materiały PISM, Zeszyty Niemcoznawcze, 4), s. 32. 
Znacznie konkretniej wypowiadał się ówczesny minister spraw zagranicznych Klaus Kinkel, podkreślając, że Niemcy jako największe państwo Europy nie będą mogły stać z boku". Według niego „europejskość" to zasadnicza rola Niemiec. Nie oznacza to "eurocentryzmu" ani też rezygnacji z globalnego definiowania niemieckich interesów, a raczej to, że Niemcy właśnie w Europie mogą znaleźć silne „zakotwiczenie" (Verankerung) w zakresie równowagi sił i pełnej zdolności do działania. Zatem muszą pozostać wraz z Francją siłą napędową w procesie jednoczenia Europy. Działanie na rzecz jedności europejskiej nie jest sprzeczne i nie wyklucza obrony interesów narodowych. Kolejnym priorytetem, który wymieniał Kinkel, było działanie na rzecz powstania Unii Europejskiej w ścisłym związku z Rosją, Ukrainą i innymi wschodnimi sąsiadami. Wspólnota Europejska powinna być równocześnie pogłębiana, rozbudowywana i poszerzana. Kinkel podkreślał, że Niemcy wiedzą z własnego doświadczenia, jak trudna jest przebudowa z państwa bezprawia na państwo prawa, z gospodarki planowej na wolnorynkową, ale jednoznacznie opowiadał się za wejściem Polski, Węgier i Czech do NATO, co w ówczesnej perspektywie nie było takie oczywiste. Podkreślał jednak, że w tej sprawie należy działać ostrożnie, aby nie dopuścić do nowego podziału Europy w formie "rowu bezpieczeństwa", który dzieliłby Europę na dwa regiony o różniącym się poczuciu bezpieczeństwa. Kinkel widział Niemcy jako gracza globalnego, ale przede wszystkim w sferze gospodarki i kultury. Często wykorzystywał cytat ministra spraw zagranicznych Republiki Weimarskiej Waltera von Rathenau: „Die Wirtschaft ist unsere Schicksal” (gospodarka jest naszym przeznaczeniem).

Choć pozycja konstytucyjna prezydenta RFN jest bardzo słaba, to jednak ówczesny prezydent Richard von Weizsäcker cieszył się w Niemczech ogromnym autorytetem. Wsparcie, które udzielał rządowi federalnemu w kwestii formułowania celów polityki zagranicznej, miało więc duże znaczenie. Weizsäcker podkreślał rolę francusko-niemieckiego tandemu w procesie integracji europejskiej oraz konieczność poszerzenia

14. Rede Außerminister K. Kinkel, Europaeische Integration und freier Welthandel - Grundlagen unseres Wohlstandes, "Bulletin“, 19 V 1993; Rede Außerminister K. Kinkel, Die Rolle Deutschlands in der Weltpolitik, "Bulletin", 3 III 1993; Rede Außerminister K. Kinkel: Chancen der Erneuerung in Politik, Wirtschaft und Gesellschaft, "Bulletin“, 24.02.1993. 
i pogłębienia UE ${ }^{15}$. Odnosił się również do historii Niemiec (Niemcy muszą odnaleźć swoją, utraconą wcześniej "normalność"), która obliguje do zwiększonej odpowiedzialności.

\section{Cele i priorytety. Debata politologów}

Należy z naciskiem zaznaczyć, że wydarzenia lat 1989-1990 zupełnie zaskoczyły politologów niemieckich, również tych zajmujących się Europą Środkową i Wschodnią. Żaden z nich nie przewidział tak szybkiego rozpadu bloku wschodniego, zjednoczenia Niemiec, czyli obalenia istniejącego status quo. Dlatego też debata dotycząca pozycji i nowej roli Niemiec rozpoczęła się dość gwałtownie i była bardzo intensywna.

Duże znaczenie opiniotwórcze w latach 90. mieli naukowcy związani z Niemieckim Towarzystwem Polityki Zagranicznej (DGAP), przede wszystkim profesorowie Karl Kaiser i Hans W. Maull. Rozpoczęli oni pod auspicjami DGAP wydawanie kilkutomowej pracy, poświęconej w całości nowej polityce zagranicznej Niemiec ${ }^{16}$. Kompleksowy charakter ma również inna praca wydana przez DGAP - Przyszłość niemieckiej polityki zagranicznej ${ }^{17}$. Kaiser, popierając pojawiające się również w innych publikacjach postulaty dotyczące związków euroatlantyckich oraz pogłębiania i poszerzania integracji europejskiej, jako pierwszy podniósł problem zwiększenia militarnej odpowiedzialności Niemiec, opowiadając się zdecydowanie za koniecznością angażowania Bundeswehry w konflikty pozaeuropejskie w ramach akcji pokojowych. W 1993 r. na łamach "Europa Archiv" Kaiser stwierdził, iż celem niemieckiej polityki zagranicznej powinno być również uzyskanie stałego członkostwa w Radzie Bezpieczeństwa ONZ ${ }^{18}$. Postulat ten uznany za dość odważny, zaledwie 2 lata po zjednoczeniu Niemiec, stał się faktycznie jednym z oficjalnych celów niemieckiej polityki zagranicznej.

Hans W. Maull stał się autorem popularnego do dziś sformułowania Zivilmacht (mocarstwo pokojowe), którego sens objaśnił na łamach

15. Ansprache des Bundespräsidenten in Hamburg zur deutschen Aussenpolitik, "Bulletin", 07 XII 1993.

16. Deutschlands neue Außenpolitik, Bd. I, Grundlagen, Oldenburg 1994; Bd. II, Herausforderungen, Oldenburg 1995; Bd. III, Interessen und Strategien, Oldenburg 1996; Bd. IV, Institutionen und Ressourcen, Oldenburg 1998.

17. Die Zukunft der deutschen Außenpolitik. Symposium des Forschungsinstituts der Deutschen Gesellschaft für Außenpolitik am 19. Oktober 1992, Hrsg. K. Kaiser, H. W. Maull, Bonn 1992.

18. K. Kaiser, Die ständige Mitgliedschaft im Sicherheitsrat. Ein berichtiges Ziel der neuen deutschen Außenpolitik, "Europa Archiv“ 1993 Nr. 19. 
"Europa Archiv"19. Swoją koncepcję omówił w 14 tezach, a dokładniej opisał w trakcie konferencji DGAP, w referacie Mocarstwo Niemcy ${ }^{20}$. Tezy 11 i 12 dotyczą przyszłych problemów bezpieczeństwa i polityki zagranicznej Niemiec. U podstaw powinno leżeć dążenie do zapewnienia ucywilizowanej polityki międzynarodowej, jest to polityka posługująca się soft power, czyli dyplomacją, środkami nacisku gospodarczego, niwelująca przyczyny konfliktów, czyli działająca prewencyjnie. Hard power, czyli działania militarne, miałyby być stosowane tylko w wyjątkowych sytuacjach ${ }^{21}$. Zdaniem Maulla Niemcy mimo odzyskania pełnej suwerenności, nie mogą działać indywidualnie, muszą konfrontować wszystkie swoje posunięcia w ramach Wspólnoty Europejskiej, która z czasem poszerzy się również o kraje Europy Środkowej.

Dieter Senghaas, profesor politologii na Uniwersytecie w Bremie, w publikacji Jakie sa niemieckie interesy ${ }^{22}$ oraz w referacie wygłoszonym 19 października 1992 roku sformułował następujące priorytety: uzyskanie bezpiecznego otoczenia, zwłaszcza w aspekcie sytuacji społeczno-politycznej, utrzymanie powiązań w zakresie współpracy gospodarczej z zagranica, współodpowiedzialność w skali światowej ${ }^{23}$. Senghaas stwierdził jednak, iż w czasach współczesnych, po upadku bipolarnego porządku politycznego, brak klarownych linii podziału, orientacji i priorytetów w niemieckiej polityce zagranicznej.

Wilfried von Bredow i Thomas Jäger w swojej pracy Nowa niemiecka polityka zagraniczna za priorytet w aspekcie multilateralnym uznali integrację europejską, a w aspekcie bilateralnym współpracę z Francją, USA i Japonią jako mocarstwami gospodarczymi. Stosunki z Polską, Czechami,

19. H. W. Maull, Zivilmacht Bundesrepublik Deutschland. Vierzehn Thesen für neue Außenpolitik, „Europa Archiv" 1992 Nr. 10.

20. H. W. Maull, Großmacht Deutschland. Anmerkungen und Thesen, w: Die Zukunft der deutschen Außenpolitik, Symposium des Forschungsinstituts der Deutschen Gesellschaft für Außenpolitik am 19. Oktober 1992, Hrsg. K. Kaiser, H. W. Maull, Bonn 1992.

21. H. W. Maull, Großmacht..., dz. cyt., s. 53 .

22. D. Senghaas, Was sind der Deutschen Interessen, „Blätter für deutsche und internationale Politik“ 1993 Nr. 6; Deutschlands verflochtene Interessen, "Internationale Politik" 1995 Nr. 8.

23. D. Senghaas, Verflechtung und Integration, w: Die Zukunft der deutschen Ausenpolitik. Symposium des Forschungsinstituts der Deutschen Gesellschaft fur Ausenpolitik am 19. Oktober 1992, Hrsg. K. Kaiser, H. W. Maull, Bonn 1993, s. 35-53. 
Słowacją i Węgrami powinny być według autorów rozwijane w ramach kontaktów z Uniąa ${ }^{24}$.

Podsumowując należy stwierdzić, iż w kwestii formułowania celów polityki zagranicznej Niemiec zarówno wśród polityków, jak i politologów zasadniczo panowała zgodność. Przede wszystkim podkreślano elementy kontynuacji: współpracę w ramach NATO, integrację europejska, priorytet stosunków francusko-niemieckich. Jednocześnie w debacie wewnątrzniemieckiej podkreślano konieczność wzięcia większej odpowiedzialności na arenie międzynarodowej, nie definiując przy tym konkretnie, w czym miałaby się przejawiać większa aktywność.

\section{Niemcy jako mocarstwo?}

Dyskusja na temat mocarstwowej roli Niemiec toczyła się głównie w kołach naukowych i koncentrowała się przede wszystkim wokół dylematu, czy podjęcie aktywniejszej polityki międzynarodowej oznacza automatycznie przyjęcie roli mocarstwa. A jeśli tak, to czy Niemcy powinny podjąć taką rolę, i jak ewentualnie zażegnać obawy przed ich potęgą.

Jeden z niemieckich politologów Wilhelm Bruns jako zasadnicze kryteria mocarstwowości uznał znaczący, samodzielny potencjał wojskowy, odpowiedni potencjał ekonomiczny, odpowiedni potencjał polityczny oraz posiadanie określonej hegemonii kulturowej ${ }^{25}$. Przyjmując te kryteria, Bruns odrzucił ewentualną mocarstwową rolę Niemiec, gdyż nie spełniaja one przede wszystkim pierwszego warunku. Według Brunsa Niemcy będą nadal zdane na pomoc USA (ewentualnie NATO) w dziedzinie militarnej. Jedynym mocarstwem dla Brunsa są Stany Zjednoczone, natomiast Niemcy nie są i nie będą światowym mocarstwem zgodnie z klasyczną definicją tego pojęcia. Bruns widział wówczas cztery możliwe scenariusze rozwoju:

1. Orientacja skierowana na utrzymanie status quo; miałoby to oznaczać przede wszystkim kontynuację i przewidywalność polityki niemieckiej;

2. Orientacja wschodnia, związana ze spełnianiem oczekiwań krajów Europy Środkowej i Wschodniej na niemiecką pomoc polityczną i ekonomiczną (jeśli jednak cała Europa Zachodnia nie włączy się w ten proces, skutki będą trudne do przewidzenia);

24. W. von Bredow, T. Jäger, Neue Deutsche Außenpolitik, Nationale Interessen in internationalen Beziehungen, Opladen 1993.

25. W. Bruns, Deutschlands Rolle in der internationalen Politik, Bonn 1992 (Studium FES, 45). 
3. Kierownicza rola w Europie; byłaby ona bardzo trudna, gdyż z jednej strony namawia się Niemcy do przyjęcia takiej roli, a z drugiej rośnie obawa przed ich silną, mocarstwową pozycją;

4. Kierownicza rola w świecie, która wynikałaby z faktu, iż Niemcy jako kraj-eksporter mają gospodarcze powiązania z państwami na całym świecie; w przypadku takiego scenariusza musiałaby ulec globalizacji polityka zagraniczna Niemiec, a ta według Brunsa wiązałaby się z szerszym zaangażowaniem militarnym poza terytorium NATO oraz z uzyskaniem stałego miejsca w Radzie Bezpieczeństwa ONZ.

Zdecydowanie przeciw mocarstwowej polityce zjednoczonych Niemiec wypowiadał się wielokrotnie Hans W. Maull ${ }^{26}$. Za cechy konieczne, determinujące pozycję mocarstwową uznał możliwości technologiczne, które są i będą coraz bardziej podstawą przyszłej siły gospodarczej (technologia w tym przypadku jest rozumiana jako technika, jej socjalna organizacja, umiejętność i sposoby rozwiązywania problemów), siłę militarną, oraz soft power, czyli zdolność oddziaływania poprzez przekonywanie i wywieranie nacisku za pomocą argumentów innych niż militarne (np. ekonomiczne, kulturowe). Analizując sytuację Niemiec, Maull stwierdził zdecydowanie, iż nie spełniają one w wymaganym zakresie żadnego z tych kryteriów. Poziom rozwoju technologicznego Niemiec jest w porównaniu z USA i Japonią dość problematyczny, a poprzez zjednoczenie znacznie się obniżył. Kryterium militarne również nie jest spełnione w wystarczającym zakresie, przede wszystkim wskutek prawnych ograniczeń, ale również względnie niskiej liczebności armii i braku broni jądrowej. Trzeci warunek również nie jest według Maulla spełniony. Niemcy nie mają szerokich możliwości wpływania na decyzje polityczne, natomiast tam, gdzie mogłyby wywierać wpływ, pozostają najczęściej bierne. Maull nie poprzestaje jednak na zanegowaniu mocarstwowej drogi Niemiec. Przedstawia on bardzo interesująca alternatywę - Niemcy jako Zivilmacht, a więc więc mocarstwo cywilne,

26. H. W. Maull jest jednym z bardziej znanych w Niemczech politologów, należy do bardzo wpływowego Niemieckiego Towarzystwa Poltyki Zagranicznej (DGAP); rozważania nad nową sytuacją Niemiec oraz polityką zagraniczną zawarł przede wszystkim, w Großmacht..., dz. cyt., s. 53-73; Japan und Deutschland: die neue Grossmächte?, „Europa Archiv" 1994 Nr. 21; Zivilmacht..., dz. cyt.; Die Suche nach Kontinuität in einer Welt des Wandels (Maull, Kaiser), w: Deutschlands neue AuBenpolitik, Bd. 1, Grundlagen, München 1994; Internationale Politik zwischen Integration und Zerfall, w: Deutschlands neue Außenpolitik, Bd. 2, Herausforderungen, München 1995 . 
pokojowe. Określenie to jest stworzone na zasadzie przeciwieństwa do Militärmacht, czyli mocarstwa militarnego, w którym podstawowym kryterium mocarstwowości jest siła militarna. Po raz pierwszy Maull sformułował to określenie na początku 1992 roku w swoim artykule Zivilmacht Bundesrepublik Deutschland ${ }^{27}$. Pojęcie to weszło na stałe do politycznego słownictwa niemieckiego i jest często stosowane w publikacjach naukowych i publicystyce, jest również używane przez polityków.

Zivilmacht ma według Maulla podwójne znaczenie. Po pierwsze jest to mocarstwo lub supermocarstwo, które ma możliwości i wolę kształtowania polityki międzynarodowej. Po drugie mocarstwo cywilne oznacza, iż siła jest związana z pewnymi określonymi celami, oczekiwaniami i zasadami, jak też z pewnymi formami i czynnikami realizowania tej siły. Oznacza to, że w polityce międzynarodowej pojawiające się konflikty są ujęte w pewne określone reguły i ramy prawne, zakładające przede wszystkim ograniczenie używania siły, mechanizmy do stymulowania rozwoju, a tym samym zapobiegania konfliktom ${ }^{28}$. W oparciu o wymienione założenia Maull wyróżnił konkretne postulaty dotyczące niemieckiej polityki zagranicznej w czternastu tezach ${ }^{29}$. Za główny cel uznał „ucywilizowanie" polityki międzynarodowej. Oznacza to przepustowość granic narodowych, wielorakie powiązania społeczeństw, a użycie siły musi być rozwiązaniem ostatecznym $^{30}$. Niemcy, przyjmując rolę mocarstwa cywilnego, wypełnią tym samym lukę na arenie międzynarodowej i spełnią ważną rolę w "ucywilizowaniu" kontaktów międzynarodowych. Według Maulla ani USA, ani Chiny, ani Wielka Brytania i Francja nie są mocarstwami cywilnymi, gdyż te pierwsze są nadal państwami, w których dużą rolę odgrywa militaryzm, natomiast w Wielkiej Brytanii i we Francji jest nadal widoczny dualizm w myśleniu - siła cywilna czy też tradycyjne wielkie mocarstwo? Koncepcja Zivilmacht nie wykluczała udziału Niemiec w operacjach militarnych, dopuszczała je w sytuacji, gdy miały charakter operacji pokojowych (np. działanie błękitnych hełmów).

27. H. W. Maull, Zivilmacht..., dz. cyt.

28. "Blätter für deutsche und internationale Politik“ 1993 Nr. 7.

29. W. Maull, Zivilmacht..., dz. cyt.

30. Rozwiązania proponowane przez Maulla (przede wszystkim postulat otwartych granic) były jak na ówczesne czasy bardzo kontrowersyjne. Mimo że migracje nie przybierały tak potężnej skali jak obecnie, to jednak Europa Zachodnia obawiała się napływu migrantów z Europy Środkowej i Wschodniej. 
Ponieważ tezy i teoria Maulla wzbudziły duże zainteresowanie w Niemczech, wielokrotnie wyjaśniał on i uzupełniał swoją koncepcję, m.in. na konferencji w Bonn w październiku 1992 r. stwierdził, że Niemcy nie mogą prowadzić polityki zagranicznej tylko w oparciu o swoje interesy, gdyż takich działań nie zaakceptują ich sąsiedzi ${ }^{31}$. Indywidualne działanie Niemiec, bez konsultacji z partnerami politycznymi, może im jedynie zaszkodzić i wzbudzić uzasadnione resentymenty. Takie działania Maull nazwał wręcz „igraniem z ogniem". Jako potwierdzenie tej tezy podał postępowanie Niemiec w Jugosławii, które naraziło rząd niemiecki na wiele oskarżeń. Maull uważa, że rzekomy wzrost potęgi Niemiec po zjednoczeniu nie jest rzeczywisty i pozostaje raczej w sferze psychologicznej. Zasadniczym argumentem przeciw mocarstwowej roli Niemiec jest według Maulla ich historia. Zjednoczone Niemcy muszą szanować negatywne wspomnienia historyczne narodów europejskich, związane z okresem dominacji nazistowskich Niemiec w Europie, dlatego też ich polityka zagraniczna musi odznaczać się wyjątkową ostrożnością.

Mocarstwa cywilne według Maulla muszą być również państwami handlowymi, bo tylko poprzez powiązania gospodarcze mogą odgrywać znaczącą rolę w świecie i wykorzystywać soft power. W tym zakresie Niemcy posiadają wiele atutów, jako jeden z największych eksporterów na świecie.

Pojęcie Handelstaat (państwo handlowe) stało się drugą obok Zivilmacht symboliczną kategorią debaty początku lat 9o. Warto zwrócić uwagę, że koncepcja ta, oczywiście w formie adekwatnej do czasów, w których powstała, była już obecna w niemieckiej myśli filozoficzno-politycznej. W 1800 roku Johann Gottlieb Fichte wydał swój traktat o zamkniętym państwie handlowym ${ }^{32}$. Pomijając nie tak oczywiste, jak na ówczesne czasy, oparcie nowego projektu społecznego na prawach jednostki (przede wszystkim na prawie do własności), z perspektywy międzynarodowej najciekawsze wydaje się ujęcie przez Fichtego relacji międzynarodowych jako wielostronnej mediacji między różnymi typami własności. Zamknięte państwo

31. H. W. Maull, Großmacht..., dz. cyt., s. 56.

32. J. G. Fichte, Der geschlossene Handesstaat, ein philosophischer Entwurf als Anhang zur Rechtslehre, w: Johann Gottlieb Fichte's sämtliche Werke, 3. Band, Berlin 1845, s. 387-513; całość dostępna w wersji cyfrowej (https://archive.org); zob. również: J. G Fichte, Zamknięte państwo handlowe i inne pisma, Warszawa 1996, s. $317-339$. 
handlowe to kraj zamożny, który poprzez rozważne wprowadzanie reform staje się wzorem dla innych, ale równocześnie poprzez własną potęgę blokuje agresywne, militarne zapędy sąsiadów. Ci z kolei, nie mogąc zrealizować swoich celów poprzez „łupieżczą" politykę, chcąc nie chcąc muszą podążać drogą naśladownictwa i powielać rozwiązania polityczno-społeczne zamkniętego państwa handlowego. Z koncepcji Fichtego wyłania się zarys ładu międzynarodowego, światowego projektu społecznego, opartego na rozsądku obywateli i władz, mądrze zarządzających różnymi typami własności ${ }^{33}$. Fichtego wielokrotnie oskarżano o naiwność, kategoryzując jego koncepcję jako utopijną. Niezależnie od jej oceny, jednoznacznie trzeba stwierdzić, że była ona i jest inspiracją dla wielu innych projektów, idei ładu międzynarodowego, począwszy od Ludwiga von Misesa aż po współczesny liberalny pacyfizm ${ }^{34}$. Krytyka autarkicznego rozwoju i zachowań izolacjonistycznych, silne poparcie dla wspólnego rynku i globalnych powiązań gospodarczych według zwolenników takich idei powoduje naturalną i korzystną deprecjację takich kategorii jak narodowość czy granice. Upraszczając można stwierdzić, iż integracja rynków i spodziewany zysk powodują, iż wojna stanie się nieopłacalna i niepożądana. Wydaje się, że koncepcja Handelsstaat, za którą optowało tak wielu politologów i polityków niemieckich na początku lat 90., sięgała korzeniami do "zamkniętego państwa handlowego" Fichtego. Pozwalała również Niemcom na wygodne wyłączenie z dyskusji o roli Niemiec kategorii związanych z narodowością czy historią polityczną. Jako "karzeł polityczny" RFN osiągnęła mocarstwową pozycję gospodarczą nie tylko w Europie, ale i w skali światowej. Jeden z politologów niemieckich Volker Rittberger stwierdził, iż Niemcy posiadają wszystkie atrybuty państwa handlowego, a więc zainteresowanie sprawami regionalnymi, powstawaniem współzależności w skali światowej, gotowość i zdolności do kooperacji i unikania autarkii ${ }^{35}$. Czy jednak status

33. Pozjednoczeniową wiarę (i wnikające z niej działania) kolejnych rządów niemieckich w „ucywilizowanie" stosunków międzynarodowych, a nawet demokratyzację niektórych krajów nie poprzez przymus i sankcje polityczne, lecz poprzez wpływy gospodarcze i udział finansowy w różnych przedsięwzięciach z obecnej perspektywy należałoby raczej ocenić jako nieudane pomysły (Rosja, Chiny, stosunek do interwencji w Iraku i Afganistanie).

34. Szerzej zob. D. Grzybek, Handel i pokój. Geneza i ewolucja liberalnego pacyfizmu, Kraków 2015.

35. V. Rittberger, Weltmacht oder Handelsstaat, w: Die Deutsche in ihrer Welt, Berlin, München 1992; Die Bundesrepublik Deutschland - eine Weltmacht? Außenpolitik nach vierzig Jahren, "Aus Politik und Zeitgeschichte“ 1990 Nr. 4-5. 
mocarstwa handlowego, jaki niewątpliwie Niemcy posiadają, oznacza równocześnie, iż są one światowym mocarstwem w sensie politycznym? Autor odpowiada na to pytanie zdecydowanie negatywnie, gdyż mimo przewagi gospodarczej Niemiec w Europie, międzynarodowy status Niemiec jest znacznym stopniu definiowany poprzez członkostwo w Unii Europejskiej.

Pojęcie "państwo handlowe" zakłada, że na arenie międzynarodowej nie odgrywa ono roli żandarma, lecz kupca, pisze Sven Papcke ${ }^{36}$. Niemcy pełnią taką funkcję, gdyż są państwem demokratycznym, mającym interesy gospodarcze w skali światowej. Stąd też wynikają zadania dla niemieckiej polityki zagranicznej. Jest to przede wszystkim umacnianie dotychczasowych powiązań ekonomicznych i dalsza globalizacja polityki gospodarczej. Niemcy, chcąc utrzymać dotychczasowy dobrobyt, nie mają alternatywy rozwoju - są zbyt uzależnione od handlu światowego ${ }^{37}$. Zjednoczone Niemcy muszą więc pozostać państwem handlowym. I nie jest to według znanego niemieckiego politologa, Dietera Senghaasa, wyzwanie tylko dla gospodarki, ale właśnie przede wszystkim dla polityki, w tym szczególnie dla dyplomacji. Jeśli niemiecka polityka zagraniczna jako nową orientację przyjmie multilateralizm, stosunki gospodarcze uzyskają ramy polityczne, dyplomatyczne. Jednocześnie biorąc pod uwagę ciężar odbudowy nowych landów, zaangażowanie w procesy integracji europejskiej i pomoc reformującym się krajom Europy Środkowej i Wschodniej oraz działalność w organizacjach międzynarodowych, Niemcy nie będą mogły kontynuować tej polityki bez wydajnie i sprawnie działającej gospodarki. Na tym właśnie polega "ekonomizacja" polityki międzynarodowej, na którą Niemcy muszą być przygotowane ${ }^{38}$.

Jeszcze inaczej przedstawił cele niemieckiej polityki zagranicznej redaktor naczelny "Handelsblatt" Reiner Nahrendorff. Według niego podstawowym zadaniem polityki zagranicznej jest stwarzanie bilateralnych i multilateralnych warunków ramowych (szczególnie w Unii Europejskiej,

36. S. Papcke, Die deutsche Innen- und Außenpolitik auf dem Prüfstand, „Das Parlament", 24-31 XII 1993.

37. D. Senghaas, Verflechtung..., dz. cyt., s. $36-40$.

38. D. Senghaas, Verflechtung..., dz. cyt., s. 43; D. Senghaas, Was sind der Deutschen Interessen, "Blätter für deutsche und internationale Politik" 1993 Nr. 6; Deutschlands verflochtene Interessen, „Internationale Politik" 1995 Nr. 8. 
OECD, GATT, WTO), w których konkurencja i handel byłyby „możliwie wolne ${ }^{\prime \prime 39}$.

Politycy niemieccy często wypowiadali się na temat nowej roli Niemiec, ustosunkowując się do ocen i teorii tworzonych przez politologów, historyków i ekonomistów. Richard von Weizsäcker w trakcie swojej kadencji prezydenckiej wielokrotnie wypowiadał się przeciwko mocarstwowej roli Niemiec, w klasycznym tego słowa znaczeniu ${ }^{40}$. Opowiadał się raczej za ideą państwa handlowego. W czasie sympozjum Instytutu Badań nad Pokojem i Bezpieczeństwem w Hamburgu (2 grudnia 1993) określił Niemcy jako Handelsmacht, a więc mocarstwo handlowe, w którego interesie jest rozwój wolnego handlu i konstruktywnej, przyjaznej konkurencji1 .

Minister spraw zagranicznych Niemiec, Klaus Kinkel, mówił wielokrotnie w swoich przemówieniach i wywiadach o nowej roli i pozycji Niemiec w Europie i w świecie, która jest postrzegana przez rząd przede wszystkim przez pryzmat gospodarki ${ }^{42}$. To właśnie powiązania ekonomiczne Niemiec miały wyznaczać priorytety polityki zagranicznej. Niemcy jako potęga gospodarcza posiadają silną pozycję w różnych organizacjach ekonomicznych. Największy wpływ mogą wywierać poprzez grupę G-7 i Międzynarodowy Fundusz Walutowy. Wielu polityków, nie tylko niemieckich, uważało, że Niemcy nie wykorzystują w pełni swojej silnej pozycji. Nadal w wielu dziedzinach pozostawały państwem pasywnym, choć zarówno w opinii międzynarodowej, jak i samych Niemców coraz częściej pojawiały

39. R. Nahrendorf, Deutschland braucht eine effiziente Außenwirtschaftspolitik , Internationale Politik" 1995 Nr. 1.

40. Richard von Weizsäcker od września 1939 r. do końca wojny służył w niemieckiej armii. Jego ojciec był sekretarzem stanu w ministerstwie spraw zagranicznych i generałem brygady SS, za co po wojnie był sądzony w jednym z procesów norymberskich (tzw. proces Wilhelmstrasse). Z pewnością doświadczenia rodzinne i osobiste wpłynęły na jego powściągliwą ocenę roli Niemiec.

41. R. von Weizsäcker, Zur deutschen Außenpolitik, „Bulletin“, 7 XII 1993.

42. M.in. K. Kinkel, Deutsche Außenpolitik in einer neuen Weltlage. Rede vor der Deutschen Geselschaft für Auswärtige Politik, am 24. August 1994, "Bulletin", 29 VIII 1994; Ansprache von Bundesaußenminister Klaus Kinkel, anläßlich der Feier des 125 jährige Jubiläums des Auswärtigen Amtes am 16 Januar 1995 in Bonn, „Internationale Politik" 1995 Nr. 4; Kernfrage deutscher Außenpolitik, Rede vor der DGAP am 12 Oktober in Berlin, „Bulletin“, 16 X 1995; Den Frieden festigen, unsere Sicherheit stärken und Stabilität Europas erweitern. Erklärung zum Jahreswechsel , "Bulletin“, 04.01.1994; Deutsche Außen- und Sicherheitspolitik. Rede in der Graf Stauffenberg Kaserne in Sigmaringen am 29. April 1994, "Bulletin“, 5 V 1994; Leitlinien der Außenpolitik des Vereinten Deutschlands. Rede auf dem Kongreß des Bundesverbandes Deutscher Zeitungsverläger in Berlin am 5 Oktober 1992, "Bulletin“, 7 X 1992. 
się głosy o konieczności podjęcia większej aktywności w polityce zagranicznej i obronnej.

Próby urzeczywistniania tych postulatów przez Niemcy były jednak na początku lat 90. postrzegane, szczególnie w Europie, dość ambiwalentnie. Dlatego też sytuacja niemieckich polityków, próbujących wykreować nową koncepcję polityki zagranicznej, była wyjątkowo trudna. Wymagana aktywność, większe zaangażowanie w akcje międzynarodowe ONZ czy NATO, często obracała się przeciwko Niemcom. W międzynarodowych reakcjach były widoczne przewrażliwienie na syndrom potęgi Niemiec, obawy przed zbytnią samodzielnością polityczną tego kraju. Dążenia Niemiec do uzyskania stałego miejsca w Radzie Bezpieczeństwa ONZ czy ustanowienia języka niemieckiego trzecim urzędowym językiem dyplomacji Unii Europejskiej naraziły Niemcy na wiele zarzutów ${ }^{43}$. W związku z taką postawą państw europejskich rosła w Niemczech irytacja wobec tych, czasem sprzecznych, oczekiwań. Coraz częściej pojawiało się w publicystyce pojęcie „dyplomacja książeczki czekowej" (Scheckbuch-Diplomatie), którym Niemcy określali rolę, w jakiej najchętniej widziałyby ich inne państwa. Określenie to zostało użyte po raz pierwszy przez publicystów zachodnich, którzy w ten sposób skrytykowali brak militarnego zaangażowania RFN w konflikcie w Zatoce Perskiej ${ }^{44}$. Obawy przed zdominowaniem Europy przez Niemcy (czy raczej niemiecką gospodarkę) wywoływały z jednej strony próby ograniczenia ewentualnej samowoli politycznej Niemiec, a z drugiej, poprzez nawoływanie Niemców do podjęcia większej odpowiedzialności, oczekiwano od nich zwiększenia finansowego udziału w akcjach politycznych czy humanitarnych w ramach różnych organizacji. Tak więc silna pozycja Niemiec, nawet jeśli nie prowadziły one ówcześnie polityki na tyle aktywnej, na ile pozwalały im możliwości, budziła (i budzi nadal) znaczne obawy, w dużej mierze wynikające z historycznych reminiscencji oraz z lęku o utratę własnych pozycji. Kanclerz Kohl w jednym ze swoich przemówień powiedział: „Jesteśmy krajem leżącym w centrum Europy, mającym najwięcej sąsiadów, nasza historia znacznie zaciążyła na losach tych państw. Nasz kraj ma obecnie 80 milionów mieszkańców, a nasza

43. Język niemiecki stał się językiem Europejskiej Służby Działań Zewnętrznych w $2010 \mathrm{r}$.

44. W. von Bredow, Die Außenpolitik der Bundesrepublik Deutschland: Eine Einführung, Wiesbaden 2006, s. 226; S. Bierling, Die Außenpolitik der Bundesrepublik Deutschland, München 1999, s. 279. 
gospodarka jest najsilniejsza w Europie. Czy chcemy to widzieć, czy nie, istnieją obawy przed Niemcami, które wywodzą się z przeszłości, ale również z naszej potęgi gospodarczej. Z tego powodu jest tak ważne, aby do końca tego wieku, w którym jest tak dużo biedy, nędzy i śmierci, budować zjednoczoną Europę"

Wielu polityków i naukowców podkreśla, że jedynym „lekarstwem" na obawy przed niemiecką potęga jest dalsze, silne zaangażowanie w proces integracji europejskiej. Jak pisze Peter Glotz: „Niemcy muszą uniknąć dylematu, iż są za małe, aby panować nad Europą, a za wielkie, by się jej podporządkować" ${ }^{46}$.

Warto tu jednak przytoczyć bardzo interesującą, choć odosobnioną tezę Dana Dinera, historyka, ówczesnego profesora uniwersytetu w Essen i równocześnie kierownika Instytutu Historii Niemiec w Tel Awiwie. Ocenia on dość sceptycznie „zachodnią" kulturę polityczną Niemiec, piszą iż jest ona ciągle w fazie tworzenia. Poddaje w wątpliwość, czy jest ona wystarczająco trwała, gdyż według niego jest ona jeszcze w fazie tworzenia ${ }^{47}$. W literaturze niemieckiej taka "niepewna" demokracja nosi nazwę "demokracja pięknej pogody" (Schönwetterdemokratie) - tą nazwą niektórzy publicyści i naukowcy (m.in. D. Diner) określali właśnie RFN, która według nich może nie przetrwać w okresach kryzysowych ${ }^{48}$.

Z tak ostrą oceną nie zgadzała się większość historyków i politologów, ale część z nich była zgodna, że istnieje zasadnicza różnica między innymi demokracjami Europy Zachodniej, a demokracją niemiecką. Chodzi tu przede wszystkim o dość drażliwy temat świadomości narodowej. Podczas gdy zachodnie systemy wartości są od wieków ugruntowane i przechodzą powolną ewolucję wraz ze zmianą mentalności społecznej, o tyle niemieckie źródła wartości demokratycznych nie znajdują swych zasadniczych korzeni w doświadczeniach historycznych, a nawet zostały świadomie od tych źródeł odcięte. Jednak to właśnie, według niemieckich naukowców, jest zjawiskiem pozytywnym. Podkreślają oni dość niespotykany w historii

45. H. Kohl, Standortbestimmung Deutschlands für die Herausforderungen der go-er Jahre, "Bulletin“, 27 I 1993

46. P. Glotz, Rokoko - Saal-Politik. Notizen zur deutschen Außenpolitik nach 1989, Die neue Gesellschaft, "Frankfurter Hefte“ 1995 Nr. 5.

47. Rozmowa z Danem Dinerem, "Blätter für deutsche und internationale Politik " 1995 Nr. 5 .

48. E. Jesse, Das Wiedervereinigte Deutschland - eine erweiterte oder eine neue Bundesrepublik?, Berlin 1999, s. 43; rozmowa z Danem Dinerem..., dz. cyt. 
proces zaakceptowania przez Niemców klęski w 1945 roku jako czegoś pozytywnego, co dało początek nowej demokratycznej epoce w historii Niemiec $^{49}$. Okres po 1945 został nazwany okresem normalności, w przeciwieństwie do popularnej w XIX i na początku XX wieku teorii o "specjalnej niemieckiej drodze" (odrębnej, szczególnej niemieckiej drodze rozwoju) deutsche Sonderweg.

\section{Deutsche Sonderweg?}

Termin Normalität powstał właśnie jako przeciwieństwo określenia Sonderweg. Pojęcie i konteksty, w których używany jest ten termin, zostały skrupulatnie wyjaśnione przez Huberta Orłowskiego we wstępie do zbioru tekstów "Sonderweg. Spory o niemiecka drogę odrębna ${ }^{50}$. Znacznie upraszczając, można przyjąć, iż mianem Sonderweg określa się w literaturze niemiecką historię dziewiętnasto- i dwudziestowieczną, która ostatecznie doprowadziła do niemieckiego imperializmu i wywołania dwóch wojen światowych. W dyskusji wokół roli zjednoczonych Niemiec termin Sonderweg pojawiał się najczęściej w kontekście pejoratywnym, jako ostrzeżenie przed indywidualną, samodzielną drogą Niemiec na arenie międzynarodowej. W skrajnych przypadkach przeciwnicy jakiejkolwiek zwiększonej aktywności Niemiec mianem Sonderweg określali wszelkie, nawet deklaratywne próby podjęcia przez Niemcy większej odpowiedzialności w stosunkach międzynarodowych.

Dyskusja tocząca się po 1989 roku nie jest tu bez znaczenia, gdyż jak twierdzi Wolfram Wette, pojęcie deutsche Sonderweg jest zakorzenione w niemieckiej świadomości i mentalności od prawie dwóch wieków. Dlatego właśnie fenomenem jest, iż udało się po 1945 roku nadać mu znaczenie pejoratywne w świadomości całego narodu. Mimo że od 1949 roku teza o "niemieckiej drodze" została w praktyce wyeliminowana, również w aspekcie celów politycznych, to przełomowym momentem w skali całego społeczeństwa, a nie tylko elit politycznych, okazał się rok 1968. Uważa się, że był to najważniejszy w historii RFN krok do demokratycznej "normalności" Zachodu. Problem deutsche Sonderweg po raz pierwszy przestał

49. Niezwykle interesujący wywód na ten temat przeprowadza m.in. Wolfram Wette, Sonderweg oder Normalität? Zur Diskusion um die internationale Position der Bundesrepublik, "Blätter für deutsche und internationale Politik" 1996 Nr. 1.

50. Sonderweg. Spory o niemiecka drogę odrębna, red. H. Orłowski, Poznań 2008, S. $7-50$. 
być tematem tabu w publicznych dyskusjach. Zjednoczenie Niemiec uaktualniło to zagadnienie, gdyż ponownie postawiono pytanie, jak nazwać nowy etap w historii Niemiec, skoro obok dwóch zasadniczych pojęć: negatywnego Sonderweg i pozytywnego Normalität nie funkcjonowały w historiografii niemieckiej inne pojęcia ${ }^{51}$. Propozycja "nowa normalność" (neue Normalität) nie została zaakceptowana przede wszystkim przez konserwatywnych polityków, historyków i publicystów, którzy uważali, że stawia ona pod znakiem zapytania „normalność" starej RFN. O trwałym zakorzenieniu w świadomości niemieckiej tych dwóch modeli rozwoju Niemiec świadczą również określenia przeciwników aktywności politycznej zjednoczonych Niemiec, którzy każdą próbę zwiększenia roli tego państwa określają jako dążenie do realizacji deutsche Sonderweg.

Jürgen Kocka uważał w 1992 r., że zjednoczenie Niemiec w żadnej mierze nie jest powrotem do niemieckiej drogi odrębnej, gdyż RFN jest zbyt mocno związana z Europą Zachodnią, również w sferze mentalnej, ale przede wszystkim zasadnicze znaczenie ma fakt, że odwołaniom do narodowych kontekstów w trakcie jednoczenia się Niemiec zawsze towarzyszyły odwołania do zwiększonej odpowiedzialności Niemców ${ }^{52}$.

Debata na temat niemieckiej drogi odrębnej w latach 90. nieuchronnie oscylowała wokół pojęć „naród”, „patriotyzm”, do których w okresie ziemnej wojny w zasadzie się nie odwoływano ze względu na ich negatywne konotacje. Na początku lat 90. w zachodnioniemieckich gazetach zaczęły pojawiać się felietony intelektualistów na temat roli, jaką powinny odgrywać Niemcy po zjednoczeniu. Pierwszym z ważnych artykułów był tekst K. H. Bohrera we „Frankfurter Allgemeine Zeitung" Warum wir keine Nation sind. Warum wir eine sollten ${ }^{53}$. Autor krytykuje Niemców za „brak empatii" wobec zachodnich sojuszników przy forsowaniu zjednoczenia Niemiec. Równocześnie krytykuje utożsamianie wielkości terytorium i liczby mieszkańców państwa z pojęciem narodu i mocarstwa. Naród to „zbiorowa historyczna i kulturowa pamięć", a tę niemiecką ocenia negatywnie ${ }^{54}$.

51. R. Stuth, Deutschlands neue Rolle im sich wandelnden Europa, "Aussenpolitik“ 1992 Nr. 1.

52. J. Kocka, Zmierz niemieckiej drogi odrębnej?, w: Sonderweg. Spory o niemieckq drogę odrębna, Poznań 2008, s. 399-417.

53. K. H. Bohrer, Warum wir keine Nation sind. Warum wir eine sollten, "Frankfurter Allgemeine Zeitung“, 13 I 1990; również: U. Greiner, Das Phantom der Nation, „Die Zeit", 16 III 1990.

54. U. Greiner, Das Phantom der Nation, „Die Zeit", 16 III 1990. 
Symbolem postaw konserwatywnych i lewicowych w odniesieniu do tego tematu i tych zagadnień była debata między Martinem Walserem a Güntherem Grassem ${ }^{55}$. Walser już w 1988 r. jasno i zdecydowanie opowiadał się za zjednoczeniem Niemiec i trzeba dodać, że był to wówczas głos odosobniony ${ }^{56}$. W trakcie jednoczenia się dwóch krajów, na początku 1990 r. jasno stwierdzał, że nie jest ono żadnym zagrożeniem ani dla samych Niemców, ani dla innych państw ${ }^{57}$. Pisarz wprost ostrzegał przed Habermasowskim „patriotyzmem konstytucyjnym", który ucieka od tradycyjnego patriotyzmu związanego przede wszystkim z poczuciem narodowym ${ }^{58}$. Walser wprost pytał, czy ignorowanie zagadnień związanych z narodowością, wspólnotą narodową nie jest bardziej niebezpieczne od otwartej dyskusji na ten temat ${ }^{59}$. Z kolei zdecydowanym przeciwnikiem zjednoczenia Niemiec był Günter Grass, który opowiadał się za pozostawieniem dwóch państw niemieckich lub ewentualnie jakimś rodzajem konfederacji ${ }^{60}$. Przerażała go ewentualność odrodzenia się niemieckiego nacjonalizmu, ale również podjęcia przez już zjednoczone Niemcy większej roli na arenie międzynarodowej. W jednym z artykułów przestrzegał: „Monstrum chce zostać mocarstwem"61.

Podobne zastrzeżenia co do mocarstwowej roli Niemiec formułował Peter Glotz, bardzo znany niemiecki socjolog i publicysta. Ostrzegał on głównie przed używaniem wobec zjednoczonych, aktywnych Niemiec określenia Normalität. Nie przekonywało go uzasadnienie, że Niemcy, już w pełni suwerenne, będą mogły podobnie jak Anglia czy Francja realizować swoje zadania na arenie międzynarodowej (np. biorąc militarny udział

55. Martin Walser - ur. w 1927 r. wybitny niemiecki pisarz, laureat wielu nagród literackich, zdecydowany zwolennik zjednoczenia Niemiec, co w połączeniu z jego lewicowymi poglądami było dość zaskakujące. Pod koniec lat 90. (po wydaniu powieści Śmierć krytyka i wygłoszeniu mowy Erfahrungen beim Verfassen einer Sonntagsrede) oskarżany o antysemityzm. Günter Grass - 1927-2015, wybitny niemiecki pisarz, laureat Nagrody Nobla w dziedzinie literatury (1999), zwolennik pojednania polsko-niemieckiego.

56. M. Walser, Über Deutschland reden, "Die Zeit" , 4 XI 1988.

57. F. T. Grub, "Wende" und "Einheit" im Spiegel der deutschsprachige Literatur, Bd. 1, Untersuchungen, Berlin-New York 2003, s. 179.

58. J. Habermas, Nacjonalizm spod znaku "Deutsche Mark”, w: O kondycji Niemiec. Tożsamość niemiecka w debatach intelektualistów po 1945 roku, Poznań 2008, S. $426-441$.

59. M. Walser, Deutsche Sorgen, "Der Spiegel“, 28 VI 1993, s. 40-47.

60. G. Grass, Kurze Rede eines vaterlandslosen Gesellen, "Die Zeit", 9 II 1990.

61. G. Grass, Ein Schnäppchen namens DDR, "Die Zeit“, 5 X 1990. 
w konfliktach). Uważał, że pod pojęciem „większej odpowiedzialności" i "normalizacji" może kryć się droga do Sonderweg ${ }^{62}$. „Teorie normalizacyjne" według Glotza sa jedynie instrumentami do nacjonalizacji. Hasło "większej odpowiedzialności" jest puste, gdyż nikt nie potrafi wyjaśnić, co oznacza w dzisiejszym świecie „odpowiedzialność na arenie międzynarodowej".

Na debacie historyków, politologów, pisarzy swoje największe piętno odbiła historia Niemiec. Trudno się temu dziwić, zwłaszcza że czas jednoczenia Niemiec i powstawania największego i najsilniejszego ekonomicznie państwa w Europie nieuchronnie budził negatywne skojarzenia nie tylko wśród Niemców, ale również wśród europejskich sąsiadów. Podziały na zwolenników i przeciwników zjednoczenia oraz zwiększenia roli Niemiec w polityce światowej nie zawsze przebiegały zgodnie z klasycznymi podziałami politycznymi na lewicę i prawicę. Debaty te toczyły się głównie w pierwszej połowie lat 90., ale warto zwrócić uwagę, że politycy niemieccy, niezależnie od sporów intelektualistów, musieli podejmować decyzje w konkretnych sprawach, reagować na konflikty w Europie, odnosić się do wielu ważnych wydarzeń na świecie. Z jednej strony starali się zademonstrować odzyskaną pełną suwerenność, z drugiej musieli się liczyć ze wzmożoną krytyką. Wydaje się, że ani świat, ani Europa nie były przygotowane na aktywną politykę zjednoczonych Niemiec.

\section{Krytyka wybranych działań rządu federalnego w latach 90.}

Mimo że polityka niemiecka po zjednoczeniu wydawała się bardzo ostrożna, konkretne posunięcia polityczne czy gospodarcze ściągnęły na polityków niemieckich wiele głosów krytycznych. Symboliczne znaczenie miało w stosunkach brytyjsko-niemieckich odwołanie uroczystości w Penemün$\mathrm{de}^{63}$ oraz w stosunkach polsko-niemieckich próba przeforsowania zgody na zorganizowanie uroczystości na Górze Świętej Anny w czasie pobytu kanclerza Hemuta Kohla w Polsce we wrześniu 1989 r. Właśnie tam Kohl

62. P. Glotz, Die falsche Normalisierung. Die unmerkliche Verwandlung der Deutschen 1989-bis 1994. Essays, Frankfurt am Main 1994.

63. 1 X 1992 miała odbyć się w Penemünde uroczystość z okazji 50. rocznicy wystrzelenia pierwszych rakiet V1 i V2. W wyniku wielu protestów w Wielkiej Brytanii i w Niemczech uroczystości zostały odwołane. W Peenemünde pracowali więźniowie obozów koncentracyjnych, a rakiety wystrzeliwane były m.in. na Londyn, V. C. Simon, Gefeierte Nation: Erinnerungskultur und Nationalfeiertag in Deutschland und Frankreich seit 199o, Frankfurt am Main 2007. 
chciał się spotkać z przedstawicielami mniejszości niemieckiej w Polsce, nie biorąc pod uwagę, że jest ona dla Polaków symbolem krwawych walk w czasie powstań śląskich. Te dwa incydenty, choć z punktu widzenia skutków politycznych nieposiadające większego znaczenia, wpłynęły jednak niekorzystnie na obraz Niemców, szczególnie w Polsce. Również prasa niemiecka oskarżyła wtedy kanclerza o ignorancję historyczną oraz brak wyczucia, podkreślając, że sam z wykształcenia jest historykiem. Wtedy właśnie przylgnęły do kanclerza zarzuty o brak tzw. Fingerspitzengefühl (dosł. wyczucie w końcach palców), które będą później wielokrotnie powtarzane. Brak owego wyczucia oraz powszechnie znany upór kanclerza miałyby usprawiedliwiać niektóre jego niezręczne posunięcia, równocześnie nie obciążając zarzutami polityki zagranicznej Niemiec.

Najbardziej kontrowersyjną sprawą była jednak polityka Niemiec w byłej Jugosławii. Uznanie przez Niemcy Słowenii i Chorwacji oraz naciski na Wspólnotę Europejską wywoływały ogromną falę krytyki ${ }^{64}$. Sposób postępowania Niemiec uważano za skandal, a we Francji uznanie republik Słowenii i Chorwacji nazywano w niektórych kręgach politycznych Anschlußem ${ }^{65}$. Nawet Amerykanie, którzy wówczas byli największymi sojusznikami Niemiec, mieli wiele zastrzeżeń co do formy prowadzenia polityki w Jugosławii. Boński korespondent „New York Times", David Binder, pozwolił sobie w niemieckim programie publicystycznym ARD-Presseclub na bardzo ostrą uwagę: "Niezbyt chętnie słucham z ust niemieckich polityków, w jaki sposób powinno się prowadzić wojnę na Bałkanach... Akurat oni powinni łaskawie zamknąć usta" ${ }^{66}$.

Najbardziej interesująca, krytyczną analizę polityki zagranicznej Niemiec przedstawił trzy lata po zjednoczeniu angielski dziennikarz Wiliam Horsley. Na łamach „Das Parlament" zebrał w siedmiu punktach

64. A. Heinrich, Neue deutsche Außenpolitik. Selbstversuche zwischen Zagreb und Brüssel, „Blätter für deutsche und internationale Politik“ 1991 Nr. 12; również A. Heinrich, Wunderbare Wandlung. Die Nachnachkriegsdeutschen und der Bosnien Einmarsch. Ein Frontbericht, "Blätter für deutsche und internationale Politik" 1993 Nr. 10; H.J. Axt, Hat Genscher Jugoslawien entzweit? Mythen und Fakten zur Außenpolitik des vereintes Deutschlands, "Europa Archiv" 1993 Nr. 12.

65. J. Newhouse, Bonn, der Westen und die Auflösung Jugoslawien. Das Versagen der Diplomatie - Chronik eines Skandal, „Blätter fürdeutsche und internationale Politik“ 1992 Nr. 10. Imanuel Geiss pisze w „Das Parlament” z 14 VI 1993, że w pewnych kołach politycznych we Francji popiera się Serbów, aby przeciwstawić się uznaniu przez Niemców Chorwacji i Słowenii, które pojmowane jest jako Anschluß.

66. ARD - Presseclub, 31 I 1993, cyt. za. A. Heinrich, Wunderbare Wandlung..., dz. cyt. 
naganne według niego posunięcia polityczne rządu federalnego i nazwał je siedmioma grzechami głównymi niemieckiej polityki zagranicznej ${ }^{67}$. Zaliczył do nich m.in. ogłoszenie bez konsultacji z sojusznikami europejskimi 10-punktowego planu zjednoczenia Niemiec, tzw. Planu Kohla (listopad 1989). Niemcy złamały w ten sposób obowiązujący po wojnie schemat, zgodnie z którym trzy mocarstwa zwycięskie były współodpowiedzialne za politykę niemiecką na podstawie układu z 5 czerwca 1945 r. Autor zauważył jednak, że o ile można Niemcom zarzucać w tym przypadku nietaktowne zachowanie, o tyle nie może być mowy o aroganckim nacjonalizmie.

Jako drugi grzech Horsley wymienił przedstawienie w Planie Kohla granicy polsko-niemieckiej jako kwestii otwartej, choć na arenie międzynarodowej uważano ją za już uregulowaną. Takie postawienie sprawy wywołało niepokój nie tylko w Polsce, ale i w innych krajach, związany z ewentualnymi żądaniami terytorialnymi ze strony Niemiec. Argumentacja kanclerza Kohla (postulaty te popierała CSU oraz część CDU) były następujące: uznając ostatecznie granicę na Odrze i Nysie Łużyckiej przysporzy się jedynie argumentów wyborczych skrajnej prawicy, co w związku ze wzrostem zwolenników ideologii prawicowych może mieć znaczny wpływ na losy wyborów w Niemczech.

Trzecim grzechem było niesumienne wypełnianie przyrzeczeń pomocy wojskowej w wojnie w Zatoce Perskiej. Chodzi tu przede wszystkim o obiecaną wcześniej, a niespełnioną obietnicę szerszego zaangażowania militarnego. Ministerstwo Spraw Zagranicznych miało wątpliwości, czy Niemcy faktycznie są prawnie zobowiązani do obrony Turcji przed ewentualnym atakiem wojsk irackich. Taka postawa spowodowała znaczną irytację sojuszników oraz samej Turcji, której prezydent Turgut Özal nazwał Niemcy nieodpowiedzialnym, niepewnym (unzuverlässig) sojusznikiem. Niemcy jeszcze długo potem protestowali przeciwko tym oskarżeniom, nieuwzględniającym zakazów konstytucyjnych. Autor podkreślił jednak, iż w wielu krytykach nie zwrócono uwagi na ogromny wkład finansowy Niemiec w akcję w Zatoce Perskiej ${ }^{68}$.

Czwartym grzechem popełnionym szczególnie wobec Wielkiej Brytanii i USA były plany utworzenia niemiecko-francuskiej brygady

67. W. Horsley, Die sieben Kardinalsünde deuscher Außenpolitik, "Das Parlament", 24-31 VII 1992.

68. C. Schreer, Die Rolle Deutschlands im Irak-Krieg, http://www.iraktribunal.de/hearing190604/schreer.htm (11.07.2017). 
(tzw. urokorpus), co według Londynu i Waszyngtonu miałoby oznaczać chęć osłabienia roli NATO (Eurokorpus powstał w listopadzie 1993 r.). Piąty grzech (jakże dziś aktualny) nie dotyczył konkretnego zachowania, lecz ogólnego przekonania, że Niemcy próbują zbyt mocno wpływać na Wspólnotę Europejską, m.in. wykorzystując swoje opłaty na jej rzecz. W tej sprawie najbardziej ekstremalnie wypowiedział się brytyjski minister handlu i przemysłu Nicholas Ridley, który jesienią 1990 r. nazwał Wspólnotę Europejską "German racket" (niemiecki harmider) oraz stwierdził, że Niemcy najchętniej "komenderowaliby" we wspólnocie "jak kiedyś Adolf Hitler" ${ }^{69}$. Za takie stwierdzenie minister musiał złożyć rezygnację, ale tego typu wypowiedzi potwierdzają według Horsleya realne istnienie strachu przed potęgą niemiecką nie tylko w krajach Europy Środkowo-Wschodniej, ale również wśród zachodnich sojuszników Niemiec.

Szóstym grzechem było wymuszenie na państwach Wspólnoty Europejskiej uznania Słowenii i Chorwacji. Już przed szczytem w Maastricht Niemcy poinformowały, iż uznają niepodległość tych krajów jeszcze przed końcem 1991 r., podczas - gdy zgodnie z zaleceniami ówczesnego sekretarza generalnego ONZ Javiera Pereza de Cuellara oraz specjalnego wysłannika wspólnoty do Jugosławii lorda Petera Carringtona - należało wstrzymać decyzję o uznaniu tych republik. Najpoważniejsze zarzuty dotyczyły bezkompromisowego wymuszenia na swoich partnerach politycznych decyzji oraz całkowitego zignorowania zaleceń zarówno przedstawicieli ONZ, jak i Wspólnoty Europejskiej. Autor podkreślał także, iż motywacja takiego posunięcia ze strony Niemiec mogła być również całkiem przyziemna. Rząd federalny prawdopodobnie uległ znacznej presji społecznej. Tysiące Niemców, jak co roku, wykupiło już wczasy na wybrzeżu chorwackim. Drugim argumentem był nacisk opinii publicznej, informowanej codziennie o masakrach w Bośni, przekonanej, iż każda dyplomatyczna inicjatywa jest lepsza niż bezczynność. Ostatni grzech dotyczył sfery gospodarczej. Horsley zarzucił Niemieckiemu Bankowi Federalnemu, że bez konsultacji z innymi krajami podnosi stopy dyskontowe, co zmusza inne rządy europejskie do podobnych posunięć. Warto zauważyć, że w prasie międzynarodowej po zjednoczeniu Niemiec często używano określenia „DM Imperialismus" (imperializm marki niemieckiej)

69. M. i S. Greiffenhagen, Hypothek der Vergangenheit. Belastungen der außenpolitischen Handlungsfähigkeit, "Internaltionale Politik“ 1995 Nr. 8. 
Podsumowując, Horsley stwierdził, iż "siedem grzechów głównych" to niepokojące sygnały w polityce zagranicznej zjednoczonych Niemiec, ale w zasadzie tylko dwa z nich uznał za niebezpieczne forsowanie interesów narodowych za wszelką cenę, mianowicie sprawę polskiej granicy oraz wymuszenie uznania niepodległości Słowenii i Chorwacji. Interesujące jest twierdzenie autora, iż brakuje w Niemczech zbiorowej odpowiedzialności rządu przed parlamentem, która pozwalałaby większym gremiom decydować o polityce zagranicznej.

Do tak postawionych zarzutów ustosunkował się natychmiast profesor Wyższej Szkoły Bundeswehry w Hamburgu Christian Hacke ${ }^{70}$. W wielu punktach przyznał Horsleyowi rację, choć zarzucił mu również nieuwzględnianie całego spektrum różnorodnych uwarunkowań politycznych. W sprawie polskiej granicy Hacke przyznał, iż być może Kohl, ze względów wyborczych, zbyt późno wprost powiedział wypędzonym, iż uznanie granicy z Polską na Odrze i Nysie jest nieodwracalne. Ale jednocześnie przypomniał, że w okresie zimnej wojny RFN była jednym z ważniejszych partnerów zachodnich Polski i głównym twórcą polityki odprężenia. Rozpatrując wydarzenia 1989/1990 roku nie można abstrahować od całej historii powojennej. Zarzuty o nieodpowiedzialne zachowanie Niemiec podczas konfliktu w Zatoce Perskiej, Hacke odrzuca całkowicie. Twierdzi, iż po pierwsze Niemcy nie były przygotowane do pełnego udziału w takiej akcji, po drugie zaś były zbyt mocno uwikłane w problemy wewnętrzne. Postawa rządu niemieckiego wobec tej wojny była według autora wyborem mniejszego zła. Niemcy mogły wziąć militarny udział w tej akcji, choć zapewne naraziłyby się wtedy na zarzuty zbyt mocarstwowego zachowania, jak na państwo, które niedawno uzyskało pełną niezależność, albo wybrać drogę pomocy finansowej i logistycznej i narazić się na zarzuty unikania odpowiedzialności i niewypełniania zobowiązań wobec partnerów. Słuszność podjętych decyzji potwierdził według Hackego konflikt w Jugosławii. Tu z kolei Niemcy zostały potępione za zbytnie angażowanie się i przedwczesne uznanie Słowenii i Chorwacji, lecz faktycznie nie istniała żadna alternatywa, która pozwoliłaby innym krajom Europy na nieuznanie tych republik. Podsumowując, Hacke przedstawił kilka uwag natury ogólnej. Napisał, iż nowa polityka zagraniczna Niemiec jest krytycznie śledzona

70. Ch. Hacke, Deutschlands Rolle in Europa. Gemeinsam mit anderen Partnern Verantwortung tragen, "Das Parlament", 24-31 VII 1992. 
szczególnie w Europie. Wynikało to m.in. z faktu, iż kraje Europy Zachodniej nie były jeszcze przygotowane do traktowania zjednoczonych Niemiec jak równoprawnego, silnego partnera, a nie, jak do tej pory, juniora, który swoje decyzje musiał z nimi konsultować. Niemcy chcą podjąć większą odpowiedzialność w Europie, ale musi być ona budowana przez wszystkich partnerów z Unii Europejskiej, a nie tak jak w przypadku pomocy Europie Wschodniej, w którym większą część kosztów ponoszą sami Niemcy. Takie traktowanie Niemiec wywołuje wrażenie, że partnerzy chętnie żądają niemieckich pieniędzy czy żołnierzy, lecz niechętnie przyznają niemieckiej polityce i dyplomacji rangę odpowiadającą temu zaangażowaniu.

Do "siedmiu grzechów" niemieckiej polityki zagranicznej można również dodać politykę wobec Czeczenii i Chin, choć w obu przypadkach trzeba podkreślić, iż nie różni się ona zasadniczo od polityki innych państw. Polityka wobec Czeczenii została jasno sformułowana przez ministra Kinkela: „byłoby absolutnym błędem zagrozić partnerskim i przyjaznym stosunkom z Moskwą poprzez sankcje gospodarcze nałożone na Rosję z powodu Czeczenii" ${ }^{71}$. Niemcy podobnie jak inne kraje Europy Zachodniej uznały wojnę w Czeczenii za wewnętrzną sprawę Rosji, jednak Kinkel jednocześnie ogłosił, iż rok 1995 będzie w polityce zagranicznej rokiem ochrony praw człowieka. Ten dysonans pomiędzy deklaracjami a faktyczną polityką został wychwycony przez większość mediów niemieckich, środowiska intelektualne, organizacje ochrony praw człowieka. Nasiliły się protesty wobec brutalnego łamania praw człowieka w Czeczenii i łamania przez Rosję podpisanych umów i zobowiązań międzynarodowych. Wydaje się, iż postępowanie wobec Rosji w sprawie Czeczenii jest typową "polityką szpagatu" politycy niemieccy otwarcie krytykują Moskwę, lecz w taki sposób, by nie destabilizować sytuacji wewnętrznej w Rosji ${ }^{72}$.

Chiny stały się w latach 9o. jednym z największych i najbardziej korzystnych dla inwestorów rynków na świecie. Dlatego też rywalizacja tocząca się wówczas o pozyskiwanie koncesji i rynku zbytu była bardzo ostra. Kontrowersyjne jednak pozostaje - nie tylko w przypadku Niemiec, ale również innych krajów - pogodzenie interesów gospodarczych z Chinami z akceptacją polityczną prowadzonej przez Chiny polityki wewnętrznej.

71. K.L. Günsche, Kinkel: Rußland nicht isolieren, "Die Welt", 13 I 1995.

72. M.in. B. Conrad, Kinkel im Spagat zwischen Moral und Realpolitik, "Die Welt", 18 I 1995; H. Kohl, Rede zur Lage in Tschetschenien vor dem Deutschen Bundestag am 19. Januar 1995, "Internationale Politik“ 1995 Nr. 4. 
Najbardziej krytykowanym przez media zagraniczne i krajowe posunięciem Niemiec było spotkanie kanclerza Kohla z żołnierzami ludowej armii chińskiej, odpowiedzialnej za masakrę na placu Tienanmen. Wizyta w Chinach, w listopadzie 1995 r., przebiegała pod hasłem "Wirtschaft braucht Klima" (gospodarka wymaga odpowiedniego klimatu/atmosfery), priorytetowym znaczeniem rynku chińskiego tłumaczono zatem wizytę w armii chińskiej ${ }^{73}$.

Podsumowując tę krytykę niektórych posunięć w polityce zagranicznej zjednoczonych Niemiec, trzeba zauważyć, iż pozostaje ona pod szczególną obserwacją opinii międzynarodowej. Pomijając przypadki ewidentnych błędnych posunięć, pozostałe "grzechy" polityki zagranicznej Niemiec w przypadku innego państwa zostałyby prawdopodobnie ocenione dużo łagodniej lub w ogóle zignorowane.

Po prawie 30 latach od zjednoczenia Niemiec wiele pytań postawionych na początku lat 90. jest nadal aktualnych. Co więcej, na wiele z nich ciągle nie potrafimy odpowiedzieć. Obawy przed coraz silniejszymi Niemcami wciąż są obecne w wypowiedziach polityków europejskich. Wyraźne, widoczne w prasie nasilenie obaw nastąpiło po decyzji Wielkiej Brytanii o wystąpieniu z Unii Europejskiej (Brexit). Z kolei politycy niemieccy, uspokajając nastroje, podkreślają przywiązanie Niemiec do integracji europejskiej, praw człowieka, wartości demokratycznych. Jednak w obliczu Brexitu i słabości Francji jedynym silnym państwem w Unii Europejskiej, mającym widoczną przewagę gospodarczą i polityczną nad innymi państwami europejskimi, są Niemcy.

73. M.in. H. Bork, Diplomatie im Stechschritt, „Der Tagesspiegel“, 15 XI 1995. 


\section{Bibliografia}

H. J. Axt, Hat Genscher Jugoslawien entzweit? Mythen und Fakten zur Außenpolitik des vereintes Deutschlands, "Europa Archiv" 1993 Nr. 12, s. $351-360$.

S. Bierling, Die Außenpolitik der Bundesrepublik Deutschland, München 1999.

K. H. Bohrer, Warum wir keine Nation sind. Warum wir eine sollten, "Frankfurter Allgemeine Zeitung", 13 I 1990, dodatek specjalny, b.p.

H. Bork, Diplomatie im Stechschritt, "Der Tagesspiegel“, 15 XI 1995.

W. von Bredow, Die Außenpolitik der Bundesrepublik Deutschland: Eine Einführung, Wiesbaden 2006.

W. von Bredow, T. Jäger, Neue Deutsche Außenpolitik, Nationale Interessen in internationalen Beziehungen, Opladen 1993.

W. Bruns, Deutschlands Rolle in der internationalen Politik, Bonn 1992, (Studium FES, 45).

B. Conrad, Kinkel im Spagat zwischen Moral und Realpolitik, „Die Welt" 18 I 1995, s. 2.

Die Zukunft der deutschen Außenpolitik. Symposium des

Forschungsinstituts der Deutschen Gesellschaft für Außenpolitik am

19. Oktober 1992, K. Kaiser, H. W. Maull, Bonn 1993.

Deutschlands neue Außenpolitik, Bd. I, Grundlagen, Oldenburg 1994.

Deutschlands neue Außenpolitik, Bd. II, Herausforderungen, Oldenburg 1995.

Deutschlands neue Außenpolitik, Bd. III, Interessen und Strategien, Oldenburg 1996.

Deutschlands neue Außenpolitik, Bd. IV, Institutionen und Ressourcen, Oldenburg 1998.

D. Diner (wywiad), "Blätter für deutsche und internationale Politik“ 1995 Nr. 5, s. 545-553.

P. Glotz, Die falsche Normalisierung. Die unmerkliche Verwandlung der Deutschen 1989-bis 1994. Essays, Frankfurt am Main 1994. 
P. Glotz, Rokoko - Saal - Politik. Notizen zur deutschen Außenpolitik nach 1989, "Die neue Gesellschaft. Frankfurter Hefte" 1993 Nr. 7, s. 604-611.

G. Grass, Ein Schnäppchen namens DDR , "Die Zeit", 05 X 1990.

G. Grass, Kurze Rede eines vaterlandslosen Gesellen, "Die Zeit", 09 II 1990.

M. i S. Greiffenhagen, Hypothek der Vergangenheit. Belastungen der außenpolitischen Handlungsfähigkeit, "Internaltionale Politik" 1995 Nr. 8, s. 21-26.

U. Greiner, Das Phantom der Nation, "Die Zeit" , 16 III 1990.

F. T. Grub, "Wende" und "Einheit" im Spiegel der deutschsprachige Literatur, Bd. 1, Untersuchungen, Berlin-New York 2003.

D. Grzybek, Handel i pokój. Geneza i ewolucja liberalnego pacyfizmu, Kraków 2015.

K. L. Günsche, Kinkel: Rußland nicht isolieren, "Die Welt", 13 I 1995.

J. Habermas, Nacjonalizm spod znaku "Deutsche Mark", w: O kondycji Niemiec. Tożsamość niemiecka $w$ debatach intelektualistów po 1945 roku, Poznań 2008, s. 426-441.

Ch. Hacke, Deutschlands Rolle in Europa. Gemeinsam mit anderen Partnern Verantwortung tragen, "Das Parlament", 24-31 VII 1992.

A. Heinrich, Neue deutsche Außenpolitik. Selbstversuche zwischen Zagreb und Brüssel, "Blätter für deutsche und internationale Politik" 1991 Nr. 12, s. $1446-1458$.

A. Heinrich, Wunderbare Wandlung. Die Nachnachkriegsdeutschen und der Bosnien Einmarsch. Ein Frontbericht, „Blätter für deutsche und internationale Politik" 1993 Nr. 10, s. 406-415.

W. Horsley, Die sieben Kardinalsünde deuscher Außenpolitik, "Das Parlament", 24-31 VII 1992.

J. G. Fichte, Der geschlossene Handesstaat, ein philosophischer Entwurf als Anhang zur Rechtslehre, w: Johann Gottlieb Fichte's sämtliche Werke, 3. Bd., Berlin 1845.

J. G. Fichte, Zamknięte państwo handlowe i inne pisma, tłum. P. Dybel, R. Marszałek, R. Reszke, Warszawa 1996.

H. James, Deutsche Identität 1770-199o, Frankfurt-New York 1991.

D. Janicka, Ustawa zasadnicza w praktyce Republiki Federalnej Niemiec (1949-1989), Toruń 2009.

E. Jesse, Das Wiedervereinigte Deutschland - eine erweiterte oder eine neue Bundesrepublik?, Berlin 1999. 
K. Kaiser, Das vereinigte Deutschland in der internationalen Politik, w: Deutschlands neue Außenpolitik, Bd.1, Grundlage, München 1994, s. $1-14$.

K. Kaiser, Deutsche Außenpolitik in der Ära des Globalismus. Zwischen Interdependenz und Anarchie, "Internationale Politik" 1995 Nr. 1, s. $27-36$.

K. Kaiser, Die ständige Mitgliedschaft im Sicherheitsrat. Ein berichtiges Ziel der neuen deutschen Außenpolitik, „Europa Archiv" 1993 Nr. 19, s. $541-552$.

K. Kaiser, H. W. Maull, Die Suche nach Kontinuität in einer Welt des Wandels, w: Deutschlands neue Außenpolitik, Bd.1, Grundlagen, Oldenburg 1994.

K. Kinkel, Ansprache von Bundesaußenminister Klaus Kinkel, anläßlich der Feier des 125 jährige Jubiläums des Auswärtigen Amtes am 16 Januar 1995 in Bonn, „Bulletin der Bundesregierung”, 24 I 1995, https://www.bundesregierung.de/Content/DE/ Bulletin/1990-1999/1995/06-95_Kinkel.html (dostęp: 12.07.2017).

K. Kinkel, Chancen der Erneuerung in Politik, Wirtschaft und Gesellschaft, "Bulletin der Bundesregierung “, 24 II 1993, , https://www. bundesregierung.de/Content/DE/Bulletin/1990-1999/1993/16-93_ Kinkel.html (dostęp: 15.07.2017).

K. Kinkel, Den Frieden festigen, unsere Sicherheit stärken und Stabilität Europas erweitern. Erklärung zum Jahreswechsel, „Bulletin der Bundesregierung “, 4 I 1994, s. 3-4.

K. Kinkel, Deutsche Außen- und Sicherheitspolitik. Rede in der Graf Stauffenberg Kaserne in Sigmaringen am 29. April 1994, "Bulletin der Bundesregierung “, 05 V 1994. https://www.bundesregierung.de/ Content/DE/Bulletin/1990-1999/1994/40-94_Kinkel.html (dostęp: 18.07.2017)

K. Kinkel, Deutsche Außenpolitik in einer neuen Weltlage. Rede vor der Deutschen Geselschaft für Auswärtige Politik, am 24. August 1994, "Bulletin der Bundesregierung “, 29 VIII 1994, https://www. bundesregierung.de/Content/DE/Bulletin/1990-1999/1994/76-94_ Kinkel.html (dostęp: 10.07.2017).

K. Kinkel, Die Rolle Deutschlands in der Weltpolitik, "Bulletin der Bundesregierung “, 03 III 1993, https://www.bundesregierung.de/ Content/DE/Bulletin/1990-1999/1993/18-93_Kinkel.html (dostęp: 15.07.2017). 
K. Kinkel, Europaeische Integration und freier Welthandel - Grundlagen unseres Wohlstandes, "Bulletin der Bundesregierung“, 19 V 199, https://www.bundesregierung.de/Content/DE/ Bulletin/1990-1999/1993/41-93_Kinkel.html (dostęp: 12.07.2017).

K. Kinkel, Kernfrage deutscher Außenpolitik, Rede vor der DGAP am 12 Oktober in Berlin, "Bulletin der Bundesregierung“, 16 X 1995, https://www.bundesregierung.de/Content/DE/ Bulletin/1990-1999/1995/82-95_Kinkel.html (dostęp: 17.07.2017).

K. Kinkel, Leitlinien der Außenpolitik des Vereinten Deutschlands. Rede auf dem Kongreß des Bundesverbandes Deutscher Zeitungsverläger in Berlin am 5 Oktober 1992, "Bulletin der Bundesregierung“, 7 X 1992, https://www.bundesregierung.de/Content/DE/ Bulletin/1990-1999/1992/109-92_Kinkel.html (dostęp: 15.07.2017).

H. Kohl, Die rolle deutschlands in Europa - Rede des Bundeskanzlers auf der Tagung "Forum für Deutschland" in Berlin, "Bulletin der Bundesregierung “, 22.03.1991 https://www.bundesregierung.de/ Content/DE/Bulletin/1990-1999/1991/33-91_Kohl.html (dostęp: 13.07.2017).

H. Kohl, Offizieller Besuch des Bundeskanzlers in Indien, Singapur, Indonesien, Japan und Korea vom 18. Februar bis 3. März 1993 "Bulletin der Bundesregierung “, 10 II 1993, https://www. bundesregierung.de/Content/DE/Bulletin/1990-1999/1993/20-93_ Kohl_1.html (dostęp: 13.07.2017).

H. Kohl, Rede zur Lage in Tschetschenien vor dem Deutschen Bundestag am 19. Januar 1995, "Internationale Politik“ 1995 Nr. 4, https://www. bundesregierung.de/Content/DE/Bulletin/1990-1999/1995/05-95_ Kohl.html (dostęp: 13.07.2017).

H. Kohl, Standortbestimmung Deutschlands für die Herausforderungen der go-er Jahre, „Bulletin der Bundesregierung “, 27 I 1993., s. 1.

H. W. Maull, Großmacht Deutschland. Anmerkungen und Thesen, w: Die Zukunft der deutschen Außenpolitik, Symposium des Forschungsinstituts der Deutschen Gesellschaft für Außenpolitik am 19. Oktober 1992, Bonn 1993, s. 53-72.

H. W. Maull, Internationale Politik zwischen Integration und Zerfall, w: Deutschlands neue Außenpolitik, Bd. 2, Herausforderungen, München 1995, s. 1-22.

H. W. Maull, Japan und Deutschland: die neue Grossmächte?, „Europa Archiv" 1994 Nr. 21, s. 603-610. 
H. W. Maull, Zivilmacht Bundesrepublik Deutschland. Vierzehn Thesen für neue Außenpolitik, "Europa Archiv" 1992 Nr. 10, s. 269-278.

R. Nahrendorf, Deutschland braucht eine effiziente Außenwirtschaftspolitik, "Internationale Politik" 1995 Nr. 1, s. 46-54.

J. Newhouse, Bonn, der Westen und die Auflösung Jugoslawien. Das Versagen der Diplomatie - Chronik eines Skandal, "Blätter für deutsche und internationale Politik" 1992 Nr. 10, s. 1190-1205.

S. Papcke, Die deutsche Innen- und Außenpolitik auf dem Prüfstand, „Das Parlament", 24-31 XII 1993, s. 21.

V. Rittberger, Die Bundesrepublik Deutschland - eine Weltmacht? Außenpolitik nach vierzig Jahren, "Aus Politik und Zeitgeschichte" 1990 Nr. 4-5, s. 3-19.

V. Rittberger, Weltmacht oder Handelsstaat, w: Die Deutsche in ihrer Welt, Berlin-München 1992, s. 233-263.

C. Schreer, Die Rolle Deutschlands im Irak-Krieg, http://www.iraktribunal. de/hearing190604/schreer.htm (11.07.2017).

D. Senghaas, Deutschlands verflochtene Interessen, "Internationale Politik" 1995 Nr. 8, s. 31-37.

D. Senghaas, Was sind der Deutschen Interessen, „Blätter für deutsche und internationale Politik" 1993 Nr. 6, s. 673-687.

D. Senghaas, Verflechtung und Integration, w: Die Zukunft der Deutschen Außenpolitik. Symposium des Forschungsinstituts der Deutschen Gesellschaft für Außenpolitik am 19. Oktober 1992, Bonn 1993, S. $35-52$.

V. C. Simon, Gefeierte Nation: Erinnerungskultur und Nationalfeiertag in Deutschland und Frankreich seit 199o, Frankfurt am Main 2007.

W. R. Smyser, Das Ausland und die Außenpolitik des neuen Deutschland, "Internationale Politik" 1995 Nr. 4, s. 45-50.

W. R. Smyser, The Economy of United Germany: Colossus at the Crossroads, New York 1993.

Sonderweg. Spory o niemiecka drogę odrębna, red. H. Orłowski, Poznań 2008.

R. Stuth, Deutschlands neue Rolle im sich wandelnden Europa, "Aussenpolitik" 1992 Nr. 1, s. 22-32.

M. Tomala, Dyskusja na temat polityki zagranicznej zjednoczonych Niemiec, w: Polityka zagraniczna zjednoczonych Niemiec, red. T. Pawlak-Lis, Warszawa 1994 (Studia i Materiały PISM, Zeszyty Niemcoznawcze, 4), s. 5-42. 
Urteil des Bundesverfassungsgericht zum Einsatz der Bundeswehr im Rahmen von System kollektiver Sicherheit vom 12. Juli 1994, Dokumente und Zeitgeschehen, „Blätter für deutsche und internationale Politik" 1994 Nr. 4, s. 521-525.

M. Walser, Deutsche Sorgen, "Der Spiegel", 28 VI 1993, s. 40-47.

M. Walser, Über Deutschland reden, "Die Zeit" , 4 XI 1988, s. 7.

P. Weilemann, Deutsche Außenpolitik: Herausforderungen und Verantwortung, wykład wygłoszony w Uniwersytecie Jagiellońskim, październik 1994, tekst w posiadaniu autora.

R. von Weizsäcker, Ansprache des Bundespräsidenten in Hamburg zur deutschen Aussenpolitik, "Bulletin der Bundesregierung", 07.12.1993, https://www.bundesregierung.de/Content/DE/ Bulletin/1990-1999/1993/109-93_Weizs\%C3\%A4cker.html (dostęp: 16.07.2017).

W. Wette, Sonderweg oder Normalität? Zur Diskusion um die internationale Position der Bundesrepublik, „Blätter für deutsche und internationale Politik" 1996 Nr. 1, s. 981-990. 


\title{
Abstract
}

\author{
Joanna Lubecka \\ Between fear and hope - searching for a new role of united Germany in \\ the international arena. An outline of the debates among politicians and \\ intellectuals in the early $1990 \mathrm{~s}$
}

Keywords: reunited Germany, Germany's role in the 1990s, the concept of Zivilmacht, Germany as a trade state, debate on the role of reunited Germany.
The reunification of Germany in 1990 led to the creation of the largest and most populous EU member state. Due to Germany's past and the fact that the reunification process was surprisingly fast, questions about the role and international ambitions of reunited Germany became an important part of the international debate of the time. This question had to be answered by Germans themselves in the first place. This article presents the debates among politicians and selected intellectuals (primarily political scientists and economists) who took place in Germany in the first 5 years after the reunification. It presents key contentious issues, different visions of Germany's role and contradictory expectations of international players. Its final part also quotes the then criticism of specific actions of the German government on the international scene, which reflected ambivalent, often contradictory expectations towards reunited Germany. 


\section{Abstrakt}

Joanna Lubecka

Między obawa a nadzieja - poszukiwanie nowej roli zjednoczonych

Niemiec na arenie międzynarodowej. Zarys debaty wybranych polityków

i intelektualistów w pierwszej połowie lat go.

W wyniku zjednoczenia Niemiec w 1990 r. powstało największe i najludniejsze państwo Unii Europejskiej. Ze względu na przeszłość Niemiec oraz fakt, że proces jednoczenia przebiegał zaskakująco szybko, pytania o rolę, ambicje międzynarodowe zjednoczonych Niemiec stały się istotnym elementem ówczesnej debaty międzynarodowej. Na to pytanie musieli przede wszystkim odpowiedzieć sami Niemcy. Artykuł przedstawia debatę polityków i wybranych intelektualistów (głównie politologów, ekonomistów), która odbyła się w Niemczech w pierwszych pięciu latach po zjednoczeniu. Ukazuje najważniejsze osie sporu, odmienne wizje roli Niemiec oraz sprzeczne oczekiwania międzynarodowych aktorów. W ostatnim fragmencie przedstawiono również ówczesną krytykę konkretnych działań rządu niemieckiego na arenie międzynarodowej, która odzwierciedla ambiwalentne, nierzadko sprzeczne oczekiwania wobec zjednoczonych Niemiec.

\author{
Słowa kluczowe: \\ Zjednoczone \\ Niemcy, rola \\ Niemiec w latach \\ 90., koncepcja \\ "Zivilmacht", \\ Niemcy jako \\ państwo handlowe, \\ debata o roli \\ zjednoczonych \\ Niemiec.
}


